\title{
Behavioural symptoms of mental health disorder such as depression among young people using Instagram: a systematic review
}

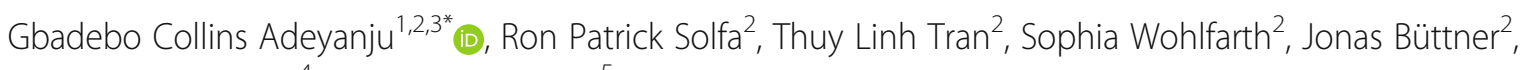
Oluyomi A. Osobajo ${ }^{4}$ and Afolabi Otitoju ${ }^{5}$

\begin{abstract}
There is a growing debate on the linkage between social networking platforms and mental health disorder, such as depressive behaviour or depression. However, the relationship between Instagram use and depression or depressive behaviour has not been exhaustively examined. This review aims to examine these two variables. Only peerreviewed journal articles that are published between October 2010 and December 2018 were sought in central and journal databases. Studies were selected based on predefined criteria and assessed for risk of bias and quality of evidence using GRADE. One thousand eight hundred fifty-six studies were the outcome of the search, out of which 9 meets all eligible criteria. Of the 9 studies, three-quarter was published between 2017 and 2018, covering five continents: (North America: 3; Asia: 2; Australia: 2; South America: 1, Europe: 1). The final included studies broadly examined young Instagram users between the age of 19 and 35. The synthesis affirmed a linkage between Instagram and symptoms of depression or depressive behaviour. Variables that moderate this relationship are social comparison, self-esteem built on validation and approval of others, social media dependence, gender, negative or insufficient feedback, poor self-rated attractiveness, Instagram broadcasting and loneliness, younger users and risk of anxiety, and the number of strangers that users follow. There is a strong relationship between Instagram use and mental health disorders such as depression or depressive behaviour; however, no in-depth direct causality is proven yet. Further studies are needed to unravel the direct causality puzzles.
\end{abstract}

Keywords: Instagram use, Depression, Mental health disorder, Social media, Self-esteem, Depressive behaviour, Women, Young people

\section{Background}

The world of social media, which involves using computer-based technology that fosters sharing information, thoughts, videos, pictures and ideas through virtual networks and communities, is changing and evolving. Instagram, a visual platform for capturing and sharing

\footnotetext{
* Correspondence: gbadebo.adeyanju@uni-erfurt.de

${ }^{1}$ Centre for Empirical Research in Economics and Behavioural Science (CEREB), University of Erfurt, Nordhäuser Str 63, 99089 Erfurt, Germany ${ }^{2}$ Media and Communication Science, University of Erfurt, Erfurt, Germany Full list of author information is available at the end of the article
}

video and photo, remains one of the fastest-growing social media platforms [1]. Compared with other social network sites, Fig. 1 revealed that while Instagram and Facebook continue to experience an upward trend, twitter experienced a static movement. This is consistent with the argument that the visual platform has experienced significant growth in the last decade with over one billion monthly active users and about $71 \%$ of the one billion users under 35 years old [2]. This aligns with the assertion that "the most common age range is between 25-34 years of age, followed by users between 18-

(c) The Author(s). 2021 Open Access This article is licensed under a Creative Commons Attribution 4.0 International License, which permits use, sharing, adaptation, distribution and reproduction in any medium or format, as long as you give appropriate credit to the original author(s) and the source, provide a link to the Creative Commons licence, and indicate if changes were made. The images or other third party material in this article are included in the article's Creative Commons licence, unless indicated otherwise in a credit line to the material. If material is not included in the article's Creative Commons licence and your intended use is not permitted by statutory regulation or exceeds the permitted use, you will need to obtain permission directly from the copyright holder. To view a copy of this licence, visit http://creativecommons.org/licenses/by/4.0/. 
24 years of age" [3]. Arguably, Instagram is engrossed with active users, just like other social network sites.

Instagram has evolved to become an influential and persuasive information avenue through which users form connections [4]. This view suggests that Instagram allows users to seek other people's opinions and views to make informed decisions. Some users could be perceived as less confident in making their own decisions, thus putting their trust in others [5]. While Instagram is regarded as an essential part of young people's daily lives, there are several dangers linked with Instagram use, specifically, adverse effects on mental health. Despite Instagram being a means to facilitate convenient connections with family members, old and new friends, it can be harmful to users' mental health [6]. Although, studies have linked users of social media to behaviour associated with mental health disorder such as depression, anxiety, poorer sleep quality, lower self-esteem, inattention, and hyperactivity - often in teens and adolescents; however, Instagram seem to have disproportionate negative impact than others $[1,6]$.

Instagram impacts users' self-esteem and influences their levels of loneliness and depression [7]. In this day and age, Instagram users' self-esteem is often influenced by bloggers and influencers' way of life as portrayed online [8]. This is because users are sometimes addicted to influencers and bloggers who directly influence their followers [9]. Bhat [10] argued that addiction to Instagram is a predictor of depression. Similarly, Instagram is perceived as a damaging social media platform that impacts young adults' mental health, hence suggesting that Instagram has become a problematic space [11, 12].

Depression is one of the most widespread and common illnesses globally, with more than 300 million people affected [13]. It significantly reduces the patient's quality of life and may lead to diminished role functioning, medical morbidity, and even suicide [14]. Depression is the leading cause of disability worldwide and is confirmed to have worldwide importance [15]. Its persistence among patients, one-third of whom diagnosed with major depressive disorder, display either a period of recurrence or recovery or even sustained symptoms over many years [16]. For this review, we characterize depression by the standards and symptoms laid out in Diagnostic and Statistical Manual of Mental Disorders (DSM-5), defining depression as a period of at least 2 weeks in which a person exhibits a depressed mood or loss of interest or pleasure in daily activities [17]. This can be accompanied by insomnia, eating disorders, lack of focus or diminished feelings of self-worth (ibid.). The DSM-5 clearly describes criteria for diagnosis of depression.

Instagram is a social networking platform that offers users opportunities to create, connect, communicate, discover and share photos and short videos as pleases. The users can choose photographic filters, which alter the tone and color of the image. Users can search and subscribe to other users in a personally curated feed, who share contents, comments and links. Instagram service reached one billion monthly active users 8 years after it was first launched [18].

\section{Active Users 2013 - 2018}

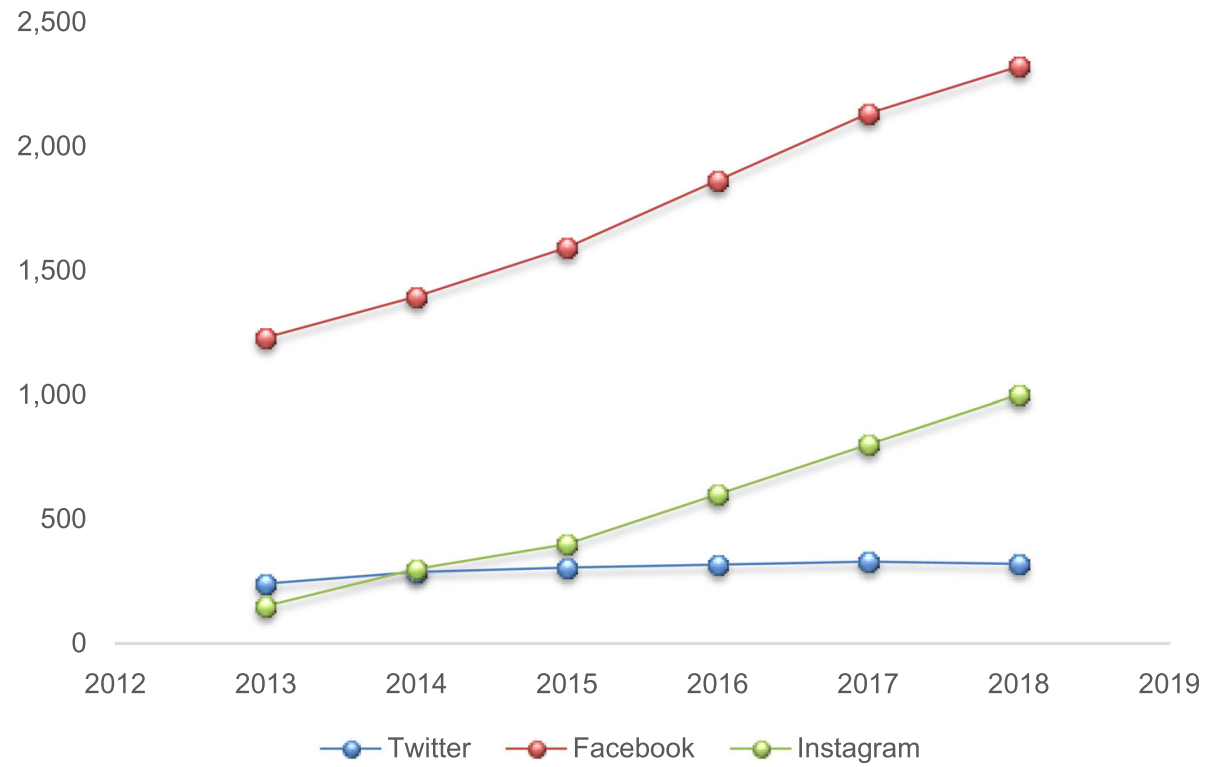

Fig. 1 Comparative graph showing number of active users worldwide between 2013 and 2018 (compiled from [2]) 
In the past, research has linked social networking platforms to mental health problems, such as feelings of isolation, body image concerns or depression. However, the relationship has not been exhaustively examined systematically $[19,20]$. Hence, this review aims to chart the linkage between Instagram and mental health disorder such as depression among users, especially young people.

\section{Method}

\section{Search strategy}

A literature search was performed using general databases and the search terms in Table 1 (English) and Table 2 (German). Peer-reviewed studies written in English and German languages and published between 1.10.2010 and 31.12.2018 were sought in PubMed via MEDLINE, EBSCOhost, Google Scholar, PsycINFO, Sage Journal, Oxford Academic, Science Direct, Taylor \& Francis, Springer Link, JSTOR and Blackwell Wiley. The search terms for English and German were developed according to Population/Participants, Intervention, Comparison and Outcome (PICO) [21, 22].

\section{Study eligibility}

Two main categories of research studies were of primary interest in this review: those relating to Instagram users and young people and depression or symptomatic behaviour of depression. Studies were included if they have been conducted on Instagram users, focusing on the relationship between Instagram and depression or symptoms of depressive behaviour as defined in the DSM-5 criteria [17]. Anxiety, loneliness or low self-esteem with a quantifiable measure of depression meet the inclusion criteria if an explicit link to depression was established in the study goal or derivation. Studies that performed research on social media in general and did not point out Instagram use and its relationship to depression were excluded. Also, there was no restriction to a particular population or geographic region. Table 3 provides a summary of studies eligible for inclusion in the review.

\section{Data collection, selection and management}

Search results from various databases were aggregated and imported into a data management software (Mendeley) to manage the screening process and selection. Studies that cannot be exported from databases were imported into Excel and manually transferred to Mendeley. Studies were screened based on title, abstract and keywords at the initial rounds and based on the full text at the final suitability stage, as represented in the Preferred Reporting Items for Systematic Reviews and Meta-Analyses (PRISMA) flow diagram in Fig. 2. Studies were screened for duplicates. Inclusion and exclusion criteria were first applied only on titles, abstracts and keywords. Those that did not meet the criteria were excluded from the final data synthesis. To ensure uniformity and synchronisation of study selection, an inter-rater reliability test was performed before data extraction.

\section{Data extraction \& data synthesis}

A pilot test on ten articles was conducted by four authors (SW, RS, LT, JB) to determine the uniformity of understanding on the inclusion and exclusion criteria. Inclusion and exclusion criteria were first applied to titles and abstracts and then full text by four reviewers (SW, RS, LT, JB). For this, the total number of studies screened were divided into roughly equal pots for each reviewer. To ensure inter-rater reliability, a kappa test was conducted [24, 25]. In three runs of 30 cases, results were compared, and disagreements were resolved through discussion between the reviewers. The kappa score rose from 0.93 to 1.00 between the three inter-rater reliability tests. The key study characteristics were collected by all researchers in a self-designed extraction form.

All reviewers undertook the descriptive data synthesis. The relationship between Instagram and depression was described, including a descriptive summary of the characteristics, connecting all the studies' findings, and exploring relationships between them. Table 4 summarises the most important study characteristics. Also, the

Table 1 Search Terms - English

\begin{tabular}{|c|c|c|c|c|c|}
\hline depress* & anxious & anxiety & "mental health" & suicid* & pessimis* \\
\hline lonel* & "self-esteem" & "self-worth" & "self- respect" & "weight gain" & "weight loss" \\
\hline alone* & desperat* & melanchol* & desponden* & unhapp* & move* \\
\hline activ* & worth- less* & discourag* & & & \\
\hline \multicolumn{6}{|l|}{ AND } \\
\hline affect $^{*}$ & effect* & relat* & associat* & rais* & increas $^{*}$ \\
\hline influenc* & impact* $^{*}$ & limit* & maximi* $^{*}$ & minimi* & impact* $^{*}$ \\
\hline determin* & enlarg* & decreas* & chang* & & \\
\hline \multicolumn{6}{|l|}{ AND } \\
\hline Instagram & & & & & \\
\hline
\end{tabular}

*The symbol is an indication of the omission of letters to denote various arbitrary meanings 
Table 2 Search Terms - German

\begin{tabular}{|c|c|c|c|c|}
\hline Depress* & Angst* & ängstlich* & Psych* & Suizid* \\
\hline Selbstmord* & Pessimist* & Einsam* & V erzweif* & Melanchol* \\
\hline Wertlos* & Selbstwert* & Selbst- vertrauen & Nieder- geschlagen* & Gewichts* \\
\hline Unglück* & Zufrieden* & Bewegung* & & \\
\hline \multicolumn{5}{|l|}{ UND } \\
\hline veränder* & einfluss* & zusammen- hang* & verbind* & verbund* \\
\hline Beziehung* & beeinfluss* & zusammen- häng* & grund* & Ursach* \\
\hline V erhält* & Gründe* & korrel* & & \\
\hline \multicolumn{5}{|l|}{ UND } \\
\hline Instagram & & & & \\
\hline
\end{tabular}

*The symbol is an indication of the omission of letters to denote various arbitrary meanings

extracted data were divided into thematic groups to identify different focuses, sum up relevant outcomes and results, and identify missing research fields. The narrative data synthesis was performed based on CRD's guidance for undertaking reviews in health care [26].

Quality of evidence and risks of bias in individual studies The methodological quality of each included studies and risk of bias was appraised by authors using the Cochrane Collaboration's tool, such as Grading of Recommendations Assessment, Development and Evaluation (GRADE), to assess the risk of bias in randomized trials [27]. Each study was rated and allocated to one of the four categories (high, medium, low or very low quality). Each included study was rated by two authors, independently of one another. Two studies that did not meet the criteria for quality were excluded from the final data synthesis. As a result, nine studies were included for the data synthesis.

\section{Result}

The selection process in the review based on the number of studies screened, assessed for eligibility, and included at each stage, is displayed in Fig. 2.

\section{Study characteristics}

Scientific journal articles (peer-reviewed) published between 2010 and 2018 forms the primary inclusion studies assessed. Two studies explored the link between Instagram and depression in women only [28, 29]. Two studies examined mostly women: $84 \%$ female participants; $78 \%$ female participants $[7,30]$. The study designs varied between questionnaires [30-35] and methodological triangulation [28, 32]. As seen in Table 4, most of the studies used already tested scales like the Beck Depression Inventory for Measuring, Rosenberg SelfEsteem Scale or the Iowa- Netherlands Comparison Orientation Measure. Study assessment showed that five studies were of moderate quality and four of low quality (see Table 5). See Table 6 in Appendix for definitions (High/Moderate/Low/Very Low). Table 4 below shows the nine eligible studies based on the selection criteria.

\section{Discussion}

The analysis revealed that there is a correlation between Instagram use and depression. Three main factors were considered in the studies. Firstly, the subject's condition, like prior depressive symptoms or other related behaviours or gender and age. Secondly, the use of Instagram, namely how frequently or in comparison to other social media such as Facebook or Twitter or by the kind of use, like following many strangers or passively browsing or actively posting. The third dimension is less about establishing the connection between Instagram and depression but finding mediators that explain why this

Table 3 Inclusion and Exclusion Criteria

\begin{tabular}{|c|c|}
\hline Included Studies & Excluded Studies \\
\hline $\begin{array}{l}\text { - All studies focusing on the relationship between Instagram and depressive symptoms or } \\
\text { display of depressive behaviour. } \\
\text { - All studies examining Instagram and depression in its different stages, including beginning } \\
\text { or signs of depression. } \\
\text { - All peer-reviewed journals, academic publications, primary studies that focus on depression } \\
\text { caused by Instagram } \\
\text { - All quantitative and qualitative studies } \\
\text { - All studies between } 01.01 .2010 \text { and } 31.12 .2018 \\
\text { - All publications in English and German language } \\
\text { - No restriction to a particular population. } \\
\text { - No restriction to a particular geographic region is set. }\end{array}$ & $\begin{array}{l}\text { - All secondary studies } \\
\text { - All systematic reviews and meta-analysis. } \\
\text { - Excluded are all articles if the outcome is not a } \\
\text { symptom of depression. } \\
\text { - All studies before } 01.01 .2010 \text { and after } 31.12 .2018 \\
\text { - Excluded are secondary studies just like narrative or } \\
\text { systematic reviews }\end{array}$ \\
\hline
\end{tabular}




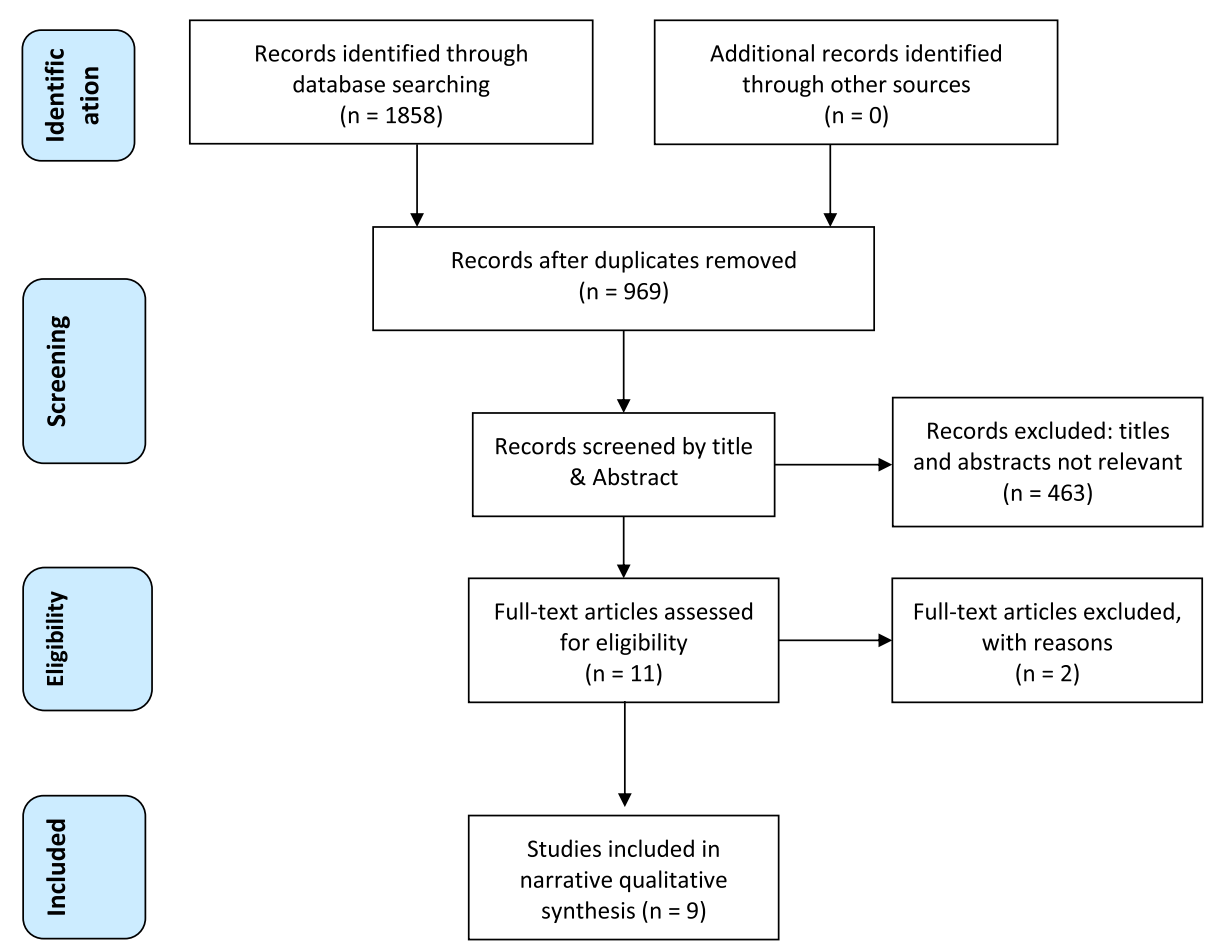

Fig. 2 Study Selection Using PRISMA Flow Diagram [23]

effect exists. Factors such as social comparison, peer feedback, self-esteem or loneliness became significant.

\section{Instagram and depression}

How Instagram is used varies from user to user. On the one hand, a differentiation between passive consumption, i.e. browsing and broadcasting, posting and direct communication such as liking a post [34]. On the other hand, Instagram usage can be divided into passive, active and interactive categories [30].

Focusing on different types of Instagram use and adolescents' depressed mood, a longitudinal two-wave panel among 12-19-year-old Flemish adolescents show that browsing leads to depressed mood and depressed mood leads to a higher posting behavior on Instagram [34]. In contrast, posting is not therapeutic for depression. Transversal analytical research from Lima, Perú shows that "the use of Instagram is [...] associated with increased risk of suffering from depressive symptoms [...]" [33]. Furthermore, measuring depressive symptoms and the dependence on social media of 212 students, results show that "there is an association between social media dependence and depressive symptoms" [33]. Using an adapted Internet addiction test to identify social media dependence, almost $70 \%$ of the 82 participating students measured had depressive symptoms [33].

\section{Instagram vs. other social networking sites}

While studies have shown that other social networking sites are related to depression [36-38], it seems reasonable for studies to examine if Instagram has distinct correlations with depression compared to other social networking sites due to its different nature in being an image-based platform. How strong is this relationship between Instagram and depression compared to other social networking sites like Facebook or Twitter?

In contrast to the correlation between Instagram and depression, users with symptoms of depression prefer Twitter over Instagram because Facebook has a protective character when it comes to depression [33]. This could be attributed to a couple of features put in place by Facebook to eliminate or reduce the negative impacts on mental well-being compared to other social media platforms, especially among young people. For example, people that connect on Facebook are friends and family who are known to each other. Besides, connections on Facebook only occurs upon the validation of an invite. Hence, the conclusion that although Facebook was the most used social media site among the 212 private university students sampled, results show that "the prioritized use of Facebook had a lower tendency of suffering from depressive symptoms" compared to Twitter and Instagram [33]. While the study has argued that Facebook is associated less with depression, the finding is not conclusive. This is because there is ample opportunity to explore further this 
Table 4 Summary of Study Findings

\begin{tabular}{|c|c|c|c|c|c|c|c|c|c|c|}
\hline \multicolumn{11}{|c|}{ Summary of Study Findings } \\
\hline \multirow{2}{*}{$\begin{array}{l}\text { S/ } \\
\text { No } \\
\end{array}$} & \multirow{2}{*}{ Study } & \multirow[t]{2}{*}{ Keywords } & \multirow[t]{2}{*}{ Instagram Focus } & \multirow{2}{*}{$\begin{array}{l}\text { Mental } \\
\text { Health }\end{array}$} & \multirow{2}{*}{$\begin{array}{l}\text { Study } \\
\text { Design }\end{array}$} & \multirow[t]{2}{*}{ Measures/Scales } & \multicolumn{4}{|c|}{ Demographics } \\
\hline & & & & & & & No. & Age & Gender & Nationality \\
\hline 1 & $\begin{array}{l}\text { Khodarahi } \\
\text { mi \& Fathi, } \\
2017\end{array}$ & $\begin{array}{l}\text { age; anxiety; } \\
\text { depression; } \\
\text { gender; } \\
\text { online social } \\
\text { messaging } \\
\text { applications; } \\
\text { stress }\end{array}$ & $\begin{array}{l}\text { Instagram as one } \\
\text { out of } 7 \text { online } \\
\text { social messaging } \\
\text { applications } \\
\text { Viber, WhatsApp, } \\
\text { Line, Telegram, } \\
\text { Tango, Instagram, } \\
\text { Facebook) }\end{array}$ & $\begin{array}{l}\text { stress, } \\
\text { anxiety, } \\
\text { depression }\end{array}$ & $\begin{array}{l}\text { Systematic } \\
\text { random } \\
\text { sampling } \\
\text { survey }\end{array}$ & $\begin{array}{l}\text { Perceived Stress } \\
\text { Scale (PSS), Beck } \\
\text { Anxiety Inventory } \\
\text { (BAI), Beck } \\
\text { Depression } \\
\text { Inventory II (BDI- II) }\end{array}$ & 440 & $\begin{array}{l}211 \\
\text { adolescents } \\
\text { (11-19yrs.). } \\
229 \text { young } \\
\text { adults (20- } \\
29 \text { yrs.) }\end{array}$ & $\begin{array}{l}M= \\
231 F= \\
209\end{array}$ & Iran \\
\hline 2 & $\begin{array}{l}\text { Weinstein, } \\
2017\end{array}$ & $\begin{array}{l}\text { adolescents; } \\
\text { emotions; } \\
\text { Instagram } \\
\text { use; social } \\
\text { browsing; } \\
\text { social } \\
\text { comparison; } \\
\text { well-being }\end{array}$ & $\begin{array}{l}\text { Instagram } \\
\text { browsing }\end{array}$ & $\begin{array}{l}\text { affective } \\
\text { well-being }\end{array}$ & $\begin{array}{l}\text { 1) } \\
\text { experimental } \\
\text { design 2) } \\
\text { semi- } \\
\text { structured } \\
\text { interviews }\end{array}$ & $\begin{array}{l}\text { Positive and } \\
\text { Negative Affect } \\
\text { Scales (PANAS) }\end{array}$ & $\begin{array}{l}\text { 1) } \\
507 . \\
\text { 2) } \\
24 .\end{array}$ & $\begin{array}{l}\text { 1) } M=15.3 \\
S D=1.0 .2) \\
M=15.7 \\
S D=1.2\end{array}$ & $\begin{array}{l}\text { 1) } m= \\
261 f= \\
239.2) \\
m=11 \\
f=13\end{array}$ & USA \\
\hline 3 & $\begin{array}{l}\text { Li et al., } \\
2018\end{array}$ & $\begin{array}{l}\text { peer } \\
\text { feedback; } \\
\text { coping; } \\
\text { depressed } \\
\text { mood; self- } \\
\text { esteem; } \\
\text { teenager; } \\
\text { social media. }\end{array}$ & $\begin{array}{l}\text { selfie-posting } \\
\text { behaviour on } \\
\text { Instagram }\end{array}$ & $\begin{array}{l}\text { peer } \\
\text { feedback } \\
\text { importance, } \\
\text { self-esteem, } \\
\text { depressed } \\
\text { mood }\end{array}$ & $\begin{array}{l}\text { Cross- } \\
\text { sectional } \\
\text { survey } \\
\text { (Paper- } \\
\text { Pencil) }\end{array}$ & $\begin{array}{l}\text { Rosenberg Self- } \\
\text { Esteem Scale, } \\
\text { Kandel Depressed } \\
\text { Mood Scale for } \\
\text { adolescents, Brief } \\
\text { COPE Inventory }\end{array}$ & 296 & $\begin{array}{l}m=14.22 \\
S D=0.82\end{array}$ & $\begin{array}{l}\text { Only } \\
\text { female }\end{array}$ & Singapore \\
\hline 4 & $\begin{array}{l}\text { Sherlock \& } \\
\text { Wagstaff, } \\
2018\end{array}$ & $\begin{array}{l}\text { social } \\
\text { networking; } \\
\text { psychological } \\
\text { I wellbeing; } \\
\text { online } \\
\text { behaviour; } \\
\text { Instagram. }\end{array}$ & Instagram use & $\begin{array}{l}\text { mental } \\
\text { health } \\
\text { outcomes } \\
\text { and self- } \\
\text { perceptions }\end{array}$ & $\begin{array}{l}\text { 1) Cross- } \\
\text { sectional } \\
\text { survey } \\
\text { 2) } \\
\text { Experiment }\end{array}$ & None & 129 & $\begin{array}{l}M=24.60 \\
S D=4.54 \\
18-35 \text { yrs }\end{array}$ & $\begin{array}{l}\text { Only } \\
\text { female }\end{array}$ & Austria \\
\hline 5 & $\begin{array}{l}\text { Jeri-Yabar } \\
\text { et al., } 2019\end{array}$ & $\begin{array}{l}\text { depression; } \\
\text { social } \\
\text { networking; } \\
\text { addictive } \\
\text { behaviour; } \\
\text { social } \\
\text { network } \\
\text { dependence. }\end{array}$ & $\begin{array}{l}\text { social media } \\
\text { dependence } \\
\text { (Facebook, } \\
\text { Twitter, } \\
\text { Instagram) }\end{array}$ & $\begin{array}{l}\text { depressive } \\
\text { symptoms }\end{array}$ & $\begin{array}{l}\text { transversal, } \\
\text { analytical } \\
\text { research }\end{array}$ & $\begin{array}{l}\text { Beck Depression } \\
\text { Inventory, Social } \\
\text { Media Addiction } \\
\text { Test }\end{array}$ & 212 & $\begin{array}{l}M=20.18- \\
35 \text { yrs. }\end{array}$ & $\begin{array}{l}m= \\
116 . f= \\
96\end{array}$ & Peru \\
\hline 6 & $\begin{array}{l}\text { Frison \& } \\
\text { Eggermont, } \\
2017\end{array}$ & $\begin{array}{l}\text { Instagram; } \\
\text { browsing; } \\
\text { posting; } \\
\text { liking; } \\
\text { depressed } \\
\text { mood; } \\
\text { adolescence }\end{array}$ & $\begin{array}{l}\text { different types of } \\
\text { Instagram use: } \\
\text { browsing; } \\
\text { posting; liking }\end{array}$ & $\begin{array}{l}\text { depressed } \\
\text { mood }\end{array}$ & $\begin{array}{l}\text { longitudinal } \\
\text { panel study }\end{array}$ & $\begin{array}{l}\text { The Center for } \\
\text { Epidemiological } \\
\text { Studies Depression } \\
\text { Scale for Children } \\
\text { (CES-DC) }\end{array}$ & 671 & $\begin{array}{l}M=14.96 \\
S D=1.29 \\
12-19 \mathrm{yrs}\end{array}$ & $\begin{array}{l}M= \\
39 \% \\
f=61 \%\end{array}$ & Belgium \\
\hline 7 & $\begin{array}{l}\text { Stapleton, } \\
\text { Luiz \& } \\
\text { Chatwin, } \\
2017\end{array}$ & $\begin{array}{l}\text { Instagram; } \\
\text { youth; social } \\
\text { networks; self- } \\
\text { esteem; social } \\
\text { comparison }\end{array}$ & $\begin{array}{l}\text { social comparison } \\
\text { and Intensity of } \\
\text { Instagram use }\end{array}$ & $\begin{array}{l}\text { self-esteem, } \\
\text { self-worth }\end{array}$ & $\begin{array}{l}\text { online } \\
\text { question } \\
\text { naire }\end{array}$ & $\begin{array}{l}\text { lowa-Netherlands } \\
\text { Comparison } \\
\text { Orientation Measure, } \\
\text { Facebook Intensity } \\
\text { Scale (adapted), } \\
\text { Rosenberg Self- } \\
\text { Esteem Scale, } \\
\text { Contingencies of } \\
\text { Self Worth Scale }\end{array}$ & 237 & $\begin{array}{l}M=23.12 \\
S D=2.17 \\
18-29 y r s\end{array}$ & $\begin{array}{l}M=93 \\
F=144\end{array}$ & Australia \\
\hline 8 & $\begin{array}{l}\text { Lup, Trub \& } \\
\text { Rosenthal, } \\
2015\end{array}$ & $\begin{array}{l}\text { Instagram } \\
\text { use, negative } \\
\text { social } \\
\text { comparison; } \\
\text { depressive }\end{array}$ & $\begin{array}{l}\text { Instagram use } \\
\text { and number of } \\
\text { strangers one } \\
\text { follows }\end{array}$ & $\begin{array}{l}\text { depressive } \\
\text { symptoms } \\
\text { through } \\
\text { negative } \\
\text { social }\end{array}$ & $\begin{array}{l}\text { online } \\
\text { questionnaire }\end{array}$ & $\begin{array}{l}\text { Center for } \\
\text { Epidemiological } \\
\text { Resources Scale for } \\
\text { Depression, Social } \\
\text { Comparison Rating }\end{array}$ & 117 & $\begin{array}{l}M=24.81 \\
S D=2.51 \\
18-29 y r s\end{array}$ & $\begin{array}{l}M= \\
16 \% \\
F=84 \%\end{array}$ & USA \\
\hline
\end{tabular}


Table 4 Summary of Study Findings (Continued)

\begin{tabular}{|c|c|c|c|c|c|c|c|c|c|c|}
\hline \multicolumn{11}{|c|}{ Summary of Study Findings } \\
\hline \multirow[t]{2}{*}{$\begin{array}{l}\text { S/ } \\
\text { No } \\
\end{array}$} & \multirow[t]{2}{*}{ Study } & \multirow{2}{*}{$\begin{array}{l}\text { Keywords } \\
\text { symptoms }\end{array}$} & \multirow[t]{2}{*}{ Instagram Focus } & \multirow{2}{*}{$\begin{array}{l}\text { Mental } \\
\text { Health } \\
\text { comparison }\end{array}$} & \multirow[t]{2}{*}{$\begin{array}{l}\text { Study } \\
\text { Design }\end{array}$} & \multirow[t]{2}{*}{ Measures/Scales } & \multicolumn{4}{|c|}{ Demographics } \\
\hline & & & & & & & & & & \\
\hline 9 & Yang, 2016 & $\begin{array}{l}\text { loneliness; } \\
\text { social } \\
\text { networking } \\
\text { site; social } \\
\text { comparison; } \\
\text { well-being; } \\
\text { social media }\end{array}$ & $\begin{array}{l}\text { social media use } \\
\text { (interaction; } \\
\text { browsing; } \\
\text { broadcasting) } \\
\text { and social media } \\
\text { comparison } \\
\text { orientation (SCO) }\end{array}$ & loneliness & Questionnaire & $\begin{array}{l}\text { lowa-Netherlands } \\
\text { Comparison } \\
\text { Orientation Measure, } \\
\text { UCLA Loneliness } \\
\text { Scale Version } 3\end{array}$ & 208 & $\begin{array}{l}M=19.43 \\
S D=1.35 \\
18-25 \mathrm{yrs}\end{array}$ & $\begin{array}{l}M= \\
22 \% \\
F=78 \%\end{array}$ & USA \\
\hline
\end{tabular}

aspect by obtaining data from other sources other than the 212 private university students sampled.

While Twitter makes users with depressive symptoms feel like someone is listening to them, undoubtedly, Instagram helps people perceive self-acceptance and elevating their low self-esteem by sharing of photos with people all over the world. This might be why Instagram is attractive to people in general. On the other hand, Instagram is at greater risk to increase the negative effects of social comparison, next to depression.

Another insight using a demographic questionnaire in conjunction with three measurements: The Perceived Stress Scale, the Beck Anxiety Inventory, and the Beck Depression Inventory-II on 440 adolescents and young adults from 440 families in Eghlid City in Iran [31]. Non-users of social media have a significantly lower level of depressive indicators $(\mathrm{M}=21.00 \mathrm{SD}=11.64)$ than social media users [31]. While WhatsApp has the lowest $(\mathrm{M}=22.79 \mathrm{SD}=12.79)$; Viber, Telegram and Facebook have moderate levels; and Instagram $(\mathrm{M}=30.42 \mathrm{SD}=$ 16.71), Line $(M=31.09 S D=11.02)$ and Tango $(M=$ $35.28 \mathrm{SD}=14.66)$ have the highest level of depressive indicators [31].

\section{Gender, age and self-esteem}

While anxiety levels varied between age groups as well as gender, females and adolescents having higher anxiety, depression and stress levels didn't differ significantly $[28,31]$. Females and older teens, in general, spend more time on social networking sites. However, older teens exhibit a more positive effect than general females' lower positive effects [32]. Hence, factors that lead to depression might be more associated with women than others.

The time spent on Instagram correlated positively with depressive symptoms and trait anxiety, social comparison orientation, appearance anxiety and body image disturbance and low self-esteem, in a study exploring the relationship between Instagram and mental health wellbeing in 129 women at the Federation University in Australia [28]. Also, the number of Instagram followers was positively associated with depression, trait anxiety and low self-esteem. As participants' age increased,
Instagram use decreased [28]. Similarly, exposure to images decreased self-rated attractiveness, implying that participants engaged in the reassessment of their notion of attractiveness and rated themselves accordingly" [28]. Hence, decreased self-rated attractiveness is associated with higher depressive symptoms, general anxiety, physical appearance consciousness, and body dissatisfaction. These social networking sites (SNS) act as aggregators for idealized imagery. Therefore, given unlimited access to other users' profiles, people are likely to engage in social comparisons.

Since age correlated negatively with Instagram use, effects might be more potent in adolescents who were not part of the sample. Also, those in the fitness and beauty groups are less likely to indulge in self-rated physical appearance because even brief exposure to idealized imagery can affect the self-assessment of one's appearance, linked to psychological well- being.

Examining the importance of peer feedback among girls on Instagram, in the form of comments, likes and number of followers, show that girls with low selfesteem are more reliant on peer feedback [29]. "The level of importance placed on receiving feedback can be considered as the magnitude to which girls stake their self-worth on the external contingencies" [29]. So, poor or insufficient feedback can lead to depressive moods. Although, this is not equated with depression but precursor-like other depressive symptoms. The importance of peer feedback is positively linked to problemfocused coping (direct action to remove the stressor) and negatively to emotion-focused coping (to minimize negative feelings) [29].

"Girls place high importance on both the number of likes and positive comments they receive. Teenage girls with low self-esteem attach higher importance to peer feedback, and the level of such importance is positively associated with depressed mood and vice versa" [29].

Therefore, peer feedback on Instagram acts as a significant predictor for behaviour effects (negative and positive). 
Table 5 Study Quality and Risk of Bias

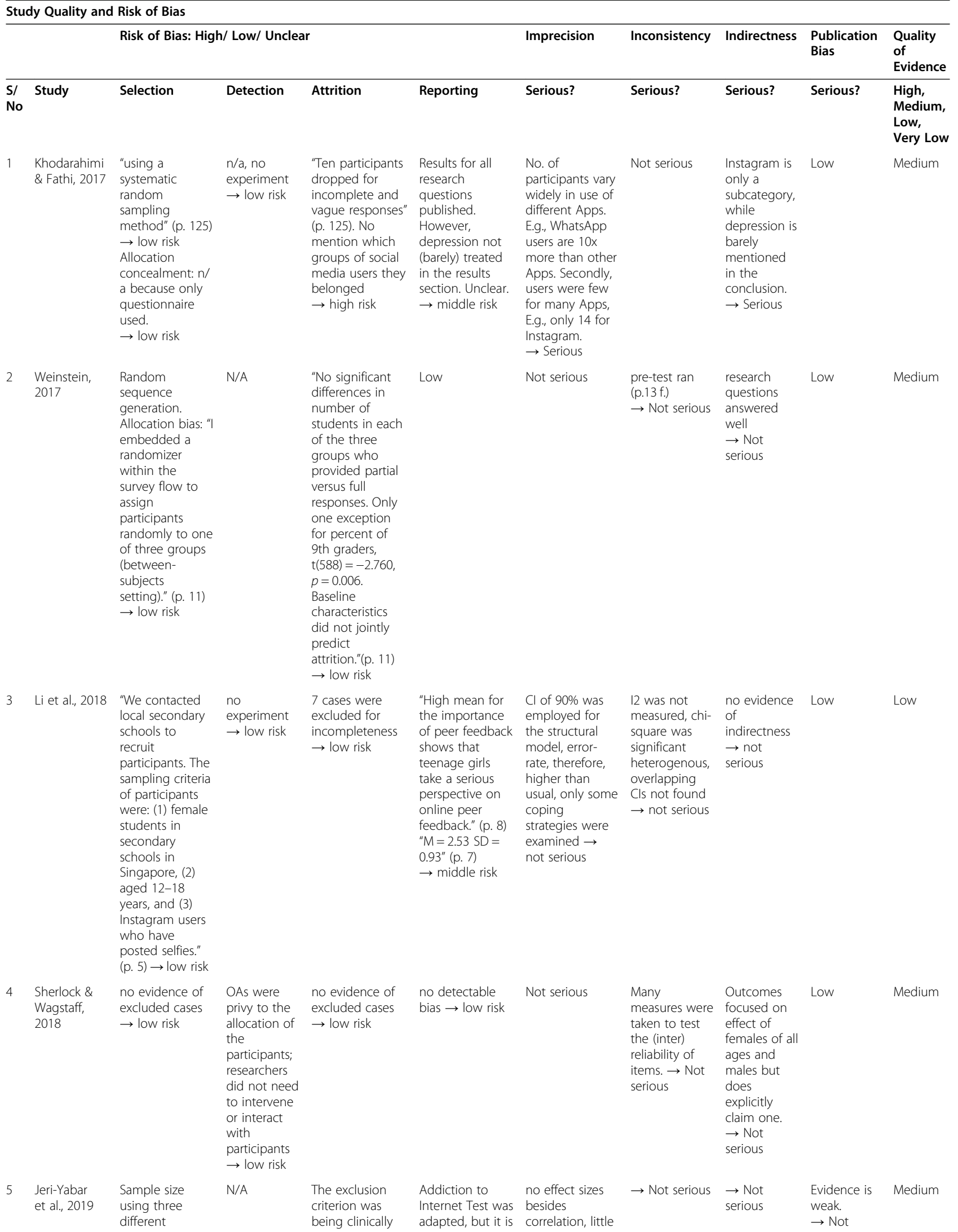


Table 5 Study Quality and Risk of Bias (Continued)

\begin{tabular}{|c|c|c|c|c|c|c|c|c|c|c|}
\hline \multicolumn{11}{|c|}{ Study Quality and Risk of Bias } \\
\hline & & \multicolumn{4}{|c|}{ Risk of Bias: High/ Low/ Unclear } & \multirow{2}{*}{$\begin{array}{l}\text { Imprecision } \\
\text { to none model } \\
\text { fit analysis } \\
\text { besides Shapiro- } \\
\text { Wilk, which is an } \\
\text { inconsistent } \\
\text { measure } \\
\rightarrow \text { high risk }\end{array}$} & \multirow[t]{2}{*}{ Inconsistency } & \multirow[t]{2}{*}{ Indirectness } & \multirow{2}{*}{$\begin{array}{l}\text { Publication } \\
\text { Bias } \\
\text { serious }\end{array}$} & \multirow{2}{*}{$\begin{array}{l}\text { Quality } \\
\text { of } \\
\text { Evidence }\end{array}$} \\
\hline & & $\begin{array}{l}\text { campuses, a } \\
\text { stratified } \\
\text { randomized } \\
\text { sample with } \\
\text { proportional } \\
\text { fixation, only } \\
\text { students } \rightarrow \\
\text { Unclear }\end{array}$ & & $\begin{array}{l}\text { diagnosed with } \\
\text { depression, } \\
\text { younger than } 18 \\
\text { and no answer. } \\
\text { (p.15). of } 397 \\
\text { students only } \\
212 \text { students left } \\
\text { for final sample } \\
\text { size, after } 13 \\
\text { losses } \rightarrow \text { low risk }\end{array}$ & $\begin{array}{l}\text { not stated how } \\
\text { exactly. Internet } \\
\text { Addiction is } \\
\text { different from } \\
\text { social media } \\
\text { addiction: no } \\
\text { differentiation } \\
\text { was stated } \\
\text { clearly between } \\
\text { social } \\
\text { networking sites } \\
\rightarrow \text { high risk }\end{array}$ & & & & & \\
\hline 6 & $\begin{array}{l}\text { Frison \& } \\
\text { Eggermont, } \\
2017\end{array}$ & $\mathrm{n} / \mathrm{a} \rightarrow$ unclear & $\begin{array}{l}\text { participants } \\
\text { knew the } \\
\text { study } \\
\text { investigated } \\
\text { their social } \\
\text { media use } \\
\text { and } \\
\text { emotions } \\
-\rightarrow \text { high risk }\end{array}$ & $\begin{array}{l}\text { "The full } \\
\text { information } \\
\text { maximum } \\
\text { likelihood } \\
\text { procedure was } \\
\text { used to estimate } \\
\text { missing data" (p. } \\
605) . \rightarrow \text { medium } \\
\text { risk }\end{array}$ & $\begin{array}{l}\text { "We decided to } \\
\text { include all } \\
\text { participants, also } \\
\text { those that did } \\
\text { not complete } \\
\text { the survey at } \\
\text { both time } \\
\text { points, (1) to } \\
\text { increase } \\
\text { statistical power } \\
\text { and (2) to } \\
\text { reduce the risk } \\
\text { of problems } \\
\text { encountered in } \\
\text { SEM when } \\
\text { sample sizes are } \\
\text { small" (p. 605). } \\
\rightarrow \text { unclear }\end{array}$ & $\rightarrow$ Serious & $\rightarrow$ Serious & $\begin{array}{l}\text { participants } \\
\text { dropped out } \\
\text { but still went } \\
\text { into data } \\
\text { analysis (p. } \\
605 \text { ). } \rightarrow \text { Not } \\
\text { serious }\end{array}$ & $\rightarrow$ Serious & Medium \\
\hline 7 & $\begin{array}{l}\text { Stapleton, } \\
\text { Luiz \& } \\
\text { Chatwin, } \\
2017\end{array}$ & $\begin{array}{l}\text { chain sampling } \\
\& \text { omnibus } \\
\text { survey } \\
\rightarrow \text { high risk }\end{array}$ & $\begin{array}{l}\mathrm{n} / \mathrm{a} \rightarrow \\
\text { Unclear }\end{array}$ & $\begin{array}{l}\text { clearly stated (p. } \\
143) \rightarrow \text { low risk }\end{array}$ & $\begin{array}{l}\text { very detailed } \\
\text { statements of } \\
\text { reporting } \rightarrow \text { low } \\
\text { risk }\end{array}$ & $\begin{array}{l}\text { high number of } \\
\text { participants } \rightarrow \\
\text { Serious }\end{array}$ & $\rightarrow$ Serious & $\begin{array}{l}\rightarrow \text { Not } \\
\text { serious }\end{array}$ & $\begin{array}{l}\rightarrow \text { Not } \\
\text { serious }\end{array}$ & Low \\
\hline 8 & $\begin{array}{l}\text { Lup, Trub \& } \\
\text { Rosenthal, } \\
2015\end{array}$ & $\begin{array}{l}\text { recruitment was } \\
\text { posted on the } \\
\text { first author's } \\
\text { Facebook page, } \\
\text { then shared by } \\
\text { other users } \rightarrow \\
\text { high risk }\end{array}$ & $\begin{array}{l}\mathrm{n} / \mathrm{a} \rightarrow \\
\text { unclear }\end{array}$ & $\begin{array}{l}\text { only one } \\
\text { participant was } \\
\text { removed } \\
\text { because of being } \\
\text { a "multivariate } \\
\text { outlier" (p. 248). } \\
\rightarrow \text { low risk }\end{array}$ & $\begin{array}{l}\text { detailed } \\
\text { statements ( } p \text {. } \\
248 \text { f.) } \rightarrow \text { low risk }\end{array}$ & $\begin{array}{l}\text { small number of } \\
\text { a very } \\
\text { homogenous } \\
\text { number of } \\
\text { participants } \rightarrow \\
\text { not serious }\end{array}$ & $\rightarrow$ Serious & $\rightarrow$ Serious & $\rightarrow$ Serious & Low \\
\hline 9 & Yang, 2016 & $\begin{array}{l}\text { "Research } \\
\text { information was } \\
\text { announced } \\
\text { through e-mail" } \\
\text { (p.704), no } \\
\text { randomization } \\
\text { mentioned } \rightarrow \\
\text { middle risk }\end{array}$ & $\begin{array}{l}\mathrm{n} / \mathrm{a}, \text { no } \\
\text { experiment } \\
\rightarrow \text { low risk }\end{array}$ & $\begin{array}{l}\text { not mentioned. } \\
\text { "all of them filled } \\
\text { out an online } \\
\text { self- report" } \\
\text { (p.705) } \rightarrow \text { middle } \\
\text { risk }\end{array}$ & $\begin{array}{l}\text { no detectable } \\
\text { bias } \\
\rightarrow \text { low risk }\end{array}$ & $\begin{array}{l}\text { a relatively high } \\
\text { number of } \\
\text { Instagram users } \\
\& \text { two } \\
\text { established } \\
\text { scales } \rightarrow \text { serious }\end{array}$ & $\rightarrow$ serious & $\rightarrow$ serious & $\begin{array}{l}\mathrm{n} / \mathrm{a} \text {, one } \\
\text { author? } \\
\rightarrow \text { unclear }\end{array}$ & Low \\
\hline
\end{tabular}

In summary, there are indications that younger users are at higher risks, and self-rating is an essential factor when talking about Instagram and depression since it is image-based. Also, peer feedback significantly affects young teenagers' self-esteem.

\section{Social comparison}

Social networking sites do not only connect people from all over the world, but they also allow users to compare themselves with others. Among all, adolescents tend to compare themselves with other individuals to learn about themselves [39]. It is reasonable to ask whether teenagers are more susceptible to depressive symptoms than adults.

Taking a closer look at depressive symptoms and social comparison among 117 Instagram users between 18 and 29 years old, "a theoretically grounded moderated mediation of the association between Instagram use and depressive symptoms through the mechanism of negative social comparison" [7]. The goal is a focus on the number of strangers the user followed and its moderating role. The findings show that the number of strangers an Instagram user follows moderates the association between Instagram use and depressive symptoms. That is, "at the highest level of strangers followed only, more 
frequent Instagram use had direct associations with greater depressive symptoms, while for those at lower levels of strangers followed, Instagram use and depressive symptoms were unrelated" [7]. In other words, if users follow a lot of people they do not know in real life, they tend to have negative psychological effects by comparing themselves to others. In the end, this evidence shows some form of relationship between Instagram use and depressive symptoms.

Assessing an experimental design with pre-post surveys and interviews, examining the role of negative comparisons in the relationship between Instagram browsing and affective well-being immediately postbrowsing in 507 students from one suburban public high school in the North-eastern United States [7]. Teens who engage in more negative comparison in response to Instagram use suffers greater threat to wellbeing. At the same time, targeted interventions (e.g. clarifying that only the best images are posted) held promise for mitigating social browsing toll among vulnerable youth [32]. The findings suggest differential susceptibility among adolescents to social media effects. Teenagers who perceived the people and objects in the feed as happy as they are with their lives didn't feel worse. I.e., people with high self-esteem perceive feeds better and don't get depressed. In contrast, while those with lower self-esteem who perceive feeds as happier than themselves get more depressed [32]. Therefore, this assessment further deepens the prior analysis, showing how self-esteem, social comparison, and depression are interlinked.

Similarly, looking at the role of social comparison in the use of Instagram among emerging adults found on the one hand that "social comparison on Instagram mediated the relationship between contingent self-worth and self-esteem "but also, that "self-worth contingent on approval from others moderated the relationship between intensity of Instagram use and social comparison" [35]. In other words, the intensity of Instagram use is influenced by the user's self-worth, which depends upon the others' approval.

High self-esteem might protect one from negative effects of social comparison and, thus, getting depressive symptoms. But if one's self-esteem depends on others' approval, people use Instagram more intensively, which leads to a greater level of social comparison, consequently [35]. Therefore, using social networking sites can damage self-esteem, especially when young people seek approval and validation from others [35]. However, Instagram does not have direct effects on self-esteem [35]. Nevertheless, self-worth and self-esteem are important symptoms; one must not underestimate when researching the connection between Instagram and depression.
Also, loneliness appears to be one of the important symptoms of depression [30, 40]. In evaluating the association between different types of Instagram use, loneliness and social comparison orientation, by analysing 208 graduate students' self-report surveys. Although passive activities are related to higher loneliness and lower wellbeing in general $[30,40,41]$, findings show that "both Instagram interaction [...] and Instagram browsing [...] were related to lower loneliness, whereas Instagram broadcasting was associated with higher loneliness" [30]. According to Social Comparison Orientation (SCO) theory, some people tend to make comparisons more than others [39]. Therefore, in this analysis, SCO associates the relationship between Instagram interaction and loneliness. I.e., social comparison related more to Instagram interaction and browsing, but not to Instagram broadcasting.

Therefore, Interactive and passive types of using Instagram (interaction and browsing) are related to lower loneliness; whereas, broadcasting, an active type of Instagram activity, was related to higher loneliness. It is possible that browsing Instagram may not be as passive as it seems. Still, it connotes actual interaction, showing that Instagram interaction of any shape espouses a feeling of connectedness, hence less loneliness. Thus, depending on how the platform was used, Instagram can lead to higher and lower loneliness.

\section{Influence of Instagram on User's behaviour}

Most of the evidence reviewed tend to support the negative outcome of Instagram on the user's behaviour. A study conducted in the United States of America observed that browsing and interacting through Instagram brings about lower loneliness in users, while broadcasting on Instagram causes higher loneliness. This suggests that Instagram users are subjected to behavioural isolation [30]. Similarly, another study conducted in Iran asserted that online social environment influences social media users' emotional state [31]. This view suggests further that the information made available through the online social environment in the form of pictures and images are instrumental in describing user's behaviour. Both indicate that inactive behaviours in Instagram activities due to its restriction to pictures and images sharing tend to displace face-to-face interaction and its benefits.

Similarly, another study conducted in Belgium found that Instagram stimulates negative comparison behaviours in users, which may increase young people's depressed mood [34]. This aligned with the one conducted in Singapore, which affirms a relationship between online peer information and teenage users' behaviour on Instagram [29]. This is because the feedback they receive via social media influences their mood and emotion. 
Hence, Australia's conclusion that, the more frequent people use social media such as Instagram, the more it influences users' psychological behaviour. That is, excessive Instagram use impact users negatively [28].

Some others view this phenomenon from plural points, not necessarily from one-way Instagram influence on user's behaviour. A study from New York found that frequent Instagram users who follow anonymous people often experience negative associations, while a positive association is experienced by users who follow fewer strangers [7]. This is in line with another analysis from the United States of America, which concluded that users' online social information often predicts their followers' behaviour negatively or positively [32]. These views suggest that both the users and their information in the online environment could positively or negatively influence an individual's experience and emotional state. Also, Instagram affects users from both developed and developing economies in almost the same way.

\section{Conclusion}

This paper aimed to examine causal relations between Instagram and depression by synthesizing studies relating to depressive symptoms and Instagram. Significant conclusions are that:

First, Instagram and depression are interlinked. Regarding the body of evidence, it seems that in general, Instagram usage intensifies depressive and related symptoms compared to non-users of Instagram and users of other social media. Also, negative effects on psychological wellbeing could occur immediately after exposure to Instagram contents, especially since the frequency of Instagram use correlates with depressive symptoms. However, it must be stated that the reasons for this correlation are not exhaustively explored yet. It could also be that depressive symptoms increase Instagram use [34].

Also, some findings have shown positive sides of using Instagram, such as feeling less lonely or connecting to people worldwide, as well as receiving positive peer feedback or positive social comparison, which prevent depressive symptoms. I.e., Instagram is a double-edged sword; it can help people with depressive symptoms getting self-acceptance and elevating their low self-esteem by sharing photos. On the other hand, Instagram poses a greater risk of increasing negative effects of social comparison and depression. Hence, users who do not receive good feedback are likely to experience depressive moods.

Second, it can be said that multiple variables influence (moderate or mediate) the connection between Instagram and depression, most notably the number of strangers one follows on Instagram and the level of social comparison. In other words, how people with depressive symptoms interact on (other) social networking sites, how they communicate with peers or how much peer feedback they receive offline must be considered to determine the effects on depression. While Facebook users are mostly connected with friends, Instagram can intensify negative effects of social comparison with strangers. Since Instagram is filled with model-like posing pictures and filtered photographs worldwide, some users might not feel good enough.

The review found different susceptibility among adolescents to social media effects. Teenagers with high self-esteem didn't get depressed, while those with lower self-esteem got more depressed by the same content. This could also explain why low self-rated attractiveness is associated with higher results for depressive behaviour. Also, social comparison on Instagram explained the relationship between self-worth and self-esteem. If one's self-esteem depends on others' approval, people use Instagram more and indulge in higher social comparison.

Third, the distinction between different types of Instagram use is important for understanding the phenomenon and the nuances under review. Interactive and passive use of Instagram (interaction and browsing) is related to lower loneliness. In contrast, broadcasting, an active type of Instagram activity, was related to higher loneliness. Therefore, further research seeking to validate these findings is needed. Also, one should not underestimate social media dependence, which associates clearly with depressive symptoms.

Fourth, most studies did not point out the differences between gender (male and female) concerning Instagram and depression. However, indications have been found that female users are at higher risk of anxiety and exhibit lower positive effect. Also, insufficient feedback for girls who perceive greater importance on peer feedback are more likely to develop depressed mood.

Fifth, age wasn't directly linked to depressive behaviour, but younger users are linked to a higher risk of anxiety, while older users exhibit higher positive effect. Using social networking sites potentially negatively affects self-esteem, especially when young people seek approval and validation from others. It might be helpful to conduct further research on Instagram users' age and symptoms of depression.

Finally, depression comes in different ways. While some studies explore depression as a concept, some studies illuminate only constituent parts of depression, such as loneliness or self-esteem and self-worth. Future studies should examine depression in relation to loneliness, self-worth, self-esteem, and anxiety in connection with Instagram usage.

While social media or social networking sites should not be regulated in any form, there is need to 


\section{Appendix}

Table 6 Quality of evidence rating [42]

\begin{tabular}{|c|c|}
\hline $\begin{array}{l}\text { Quality } \\
\text { level }\end{array}$ & Interpretation \\
\hline High & We are very confident that the true effect lies close to that of the estimate of the effect \\
\hline Moderate & $\begin{array}{l}\text { We are moderately confident in the effect estimate: The true effect is likely to be close to the estimate of the effect, but there is a } \\
\text { possibility that it is substantially different. }\end{array}$ \\
\hline Low & Our confidence in the effect estimate is limited: The true effect may be substantially different from the estimate of the effect \\
\hline Very low & We have very little confidence in the effect estimate: The true effect is likely to be substantially different from the estimate of effect \\
\hline
\end{tabular}

promote behaviour or self-agency that makes users conscious of its impact on their mental wellbeing, especially young people. It is improtant to be mindful that social media could become adictive, hence, watch the habits. Time spent on social media platforms must be limited vis-à-vis other activities. It is advisable to connect only with people or things that promote or inspire positive actions.

\section{Authors' contributions}

All authors contributed to the conceptualisation, methodology, search, screening, data extraction, result analysis and writing. The authors read and approved the final manuscript.

\section{Funding}

No funds, grants, or other support was received. Open Access funding enabled and organized by Projekt DEAL.

\section{Availability of data and materials}

The datasets generated and/or analysed during the current study are available upon request.

\section{Declarations}

Ethics approval and consent to participate

Not applicable.

\section{Consent for publication}

All authors have read and consented to the final manuscript.

\section{Competing interests}

The authors declare that they have no competing interests.

\section{Author details}

${ }^{1}$ Centre for Empirical Research in Economics and Behavioural Science (CEREB), University of Erfurt, Nordhäuser Str 63, 99089 Erfurt, Germany. ${ }^{2}$ Media and Communication Science, University of Erfurt, Erfurt, Germany. ${ }^{3}$ Psychology and Infectious Diseases Lab (PIDI), University of Erfurt, Erfurt, Germany. ${ }^{4}$ Robert Gordons University, Aberdeen, Scotland, UK. ${ }^{5}$ Africa Partners Initiative (API), Erfurt, Germany.

Received: 5 April 2021 Accepted: 6 June 2021

Published online: 07 July 2021

\section{References}

1. Sheldon P, Bryant K. Instagram: motives for its use and relationship to narcissism and contextual age. Comput Hum Behav. 2016;58:89-97. https:// doi.org/10.1016/j.chb.2015.12.059.
2. Statista 2020. Number of monthly active Instagram users from January 2013 to June 2018. (online) Retrieved from: https://www.statista.com/statistics/253 577/number-of-monthly-active-instagram-users/. Accessed 22 June 2020.

3. Marickar S, Rajasekhar D. An analysis of growth and usage patterns of Instagram users for effective brand engagement in the middle east. J Crit Rev. 2019;7(2):266

4. Thoumrungroje A. The influence of social media intensity and EWOM on conspicuous consumption. Procedia Soc Behav Sci. 2014;148:7-15. https:// doi.org/10.1016/j.sbspro.2014.07.009.

5. Wilcox K, Stephen A. Are close friends the enemy? Online social networks, self-esteem, and self-control. J Consum Res. 2013;40(1):90-103. https://doi. org/10.1086/668794

6. Hayes JF, Maughan DL, Grant-Peterkin H. Interconnected or disconnected? Promotion of mental health and prevention of mental disorder in the digital age. Br J Psychiatry. 2016:205-7.

7. Lup K, Trub L, Rosenthal L. Instagram \#instasad?: exploring associations among Instagram use, depressive symptoms, negative social comparison, and strangers followed. Cyberpsychol Behav Soc Netw. 2015;18(5):247-52. https://doi.org/10.1089/cyber.2014.0560.

8. Khamis S, Ang L, Welling R. Self-branding,'micro-celebrity'and the rise of social media influencers. Celebrity Stud. 2017;8(2):191-208. https://doi.org/1 0.1080/19392397.2016.1218292.

9. Nandagiri $V$, Philip L. Impact of influencers from Instagram and YouTube on their followers. Int J Multidiscipl Res Modern Educ. 2018;4(1):61-5.

10. Bhat SA. Social networking sites and mental health: a review. Int J Adv Educ Res. 2017;2(5):357-60.

11. Gilchrist, Karen (2017). 'Instagram most likely to cause young people to feel depressed and lonely out of major social apps, study says'. CNBC, 2017, May 19. Available at: https://www.cnbc.com/2017/05/19/instagram-most-likelyto-cause-young-people-to-feel-depressed-and-lonely-out-of-major-social-a pps-study-says.html. Accessed Dec. 3, 2020.

12. Holowka EM. Between artifice and emotion: the "sad girls" of Instagram. Leadership. Popular Cult Soc Change. 2018:183-7.

13. World Health Organisation (WHO). Mental Health. Depression: Let's Talk https://www.who.int/mental_health/management/depression/en/[24.03.201 9]. Accessed Nov. 33, 2020

14. Kessler RC, Bromet EJ. The epidemiology of depression across cultures. Annu Rev Public Health. 2013;34(1):119-38. https://doi.org/10.1146/annurevpublhealth-031912-114409.

15. Friedrich M. Depression is the leading cause of disability around the world. JAMA. 2017;317(15):1517. https://doi.org/10.1001/jama.2017.3826.

16. Walker ER, Druss BG. Rate and predictors of persistent major depressive disorder in a nationally representative sample. Community Ment Health J. 2015;51(6):701-7. https://doi.org/10.1007/s10597-014-9793-9.

17. American Psychiatric Association (APA). Diagnostic and statistical manual of mental disorders (DSM-5 ${ }^{\oplus}$ ). Washington, DC: American Psychiatric Pub; 2013.

18. Instagram. Welcome to IGTV. 2018. https://instagram-press.com/blog/2018/ 06/20/welcome-to-igtv/[25.03.2019].

19. Primack BA, Shensa A, Escobar-Viera CG, Barrett EL, Sidani JE, Colditz JB, et al. Use of multiple social media platforms and symptoms of depression 
and anxiety: a nationally- representative study among US young adults. Comput Hum Behav. 2017;69:1-9. https://doi.org/10.1016/j.chb.2016.11.013.

20. Fardouly J, Vartanian LR. Social media and body image concerns: current research and future directions. Curr Opin Psychol. 2016;9:1-5. https://doi. org/10.1016/j.copsyc.2015.09.005.

21. Miller SA. PICO worksheet and search strategy. US National Center Dental Hygiene Res. 2001

22. O'Connor D, Green S, Higgins JPT. Defining the review question and developing criteria for including studies. In: Green S, Higgins JPT, editors. Cochrane handbook for systematic reviews of interventions. Chichester: Wiley; 2008.

23. Moher D, Liberati A, Tetzlaff J, Altman DG. The PRISMA group. Preferred reporting items for systematic reviews and meta-analyses: the PRISMA statement. PLoS Med. 2009;6(7):e1000097. https://doi.org/10.1371/journal. pmed1000097.

24. Fleiss JL. Measuring nominal scale agreement among many raters. New York Psychol Bull. 1971;76(5):378-82. https://doi.org/10.1037/h0031619.

25. Cohen J. A coefficient of agreement for nominal scales. New York Educ Psychol Measure. 1960;20(1):37-46. https://doi.org/10.1177/001316446002 000104.

26. Center for Reviews and Dissemination (CRD). Guidance for undertaking reviews in health care: University of York: Center for Reviews and Dissemination; 2008.

27. Higgins JPT, Altman Douglas G, on behalf of the Cochrane Statistical Methods Group and the Cochrane Bias Methods Group. Assessing risk of bias in included studies. In: Green S, Higgins JPT, editors. Cochrane handbook for systematic reviews of interventions. Chichester: Wiley; 2008.

28. Sherlock M, Wagstaff DL. Exploring the relationship between frequency of Instagram use, exposure to idealized images, and psychological well-being in women. Psychol Pop Media Cult. 2019;8(4):482-90. https://doi.org/10.103 7/ppm0000182.

29. Li P, Chang L, Chua THH, Loh RSM. "Likes" as KPI: an examination of teenage girls' perspective on peer feedback on Instagram and its influence on coping response. Telematics Inform. 2018;35(7):1994-2005. https://doi, org/10.1016/j.tele.2018.07.003.

30. Yang CC. Instagram use, loneliness, and social comparison orientation: interact and browse on social media, but don't compare. Cyberpsychol Behav Soc Netw. 2016;19(12):703-8. https://doi.org/10.1089/cyber.2016.0201.

31. Khodarahimi S, Fathi R. The role of online social networking on emotional functioning in a sample of Iranian adolescents and young adults. J Technol Hum Serv. 2017;35(2):120-34. https://doi.org/10.1080/15228835.2017.1293 587.

32. Weinstein E. Adolescents' differential responses to social media browsing: exploring causes and consequences for intervention. Comput Hum Behav. 2017;76:396-405. https://doi.org/10.1016/j.chb.2017.07.038.

33. Jeri-Yabar, A., Sanchez-Carbonel, A., Tito, K., Ramirez-del Castillo, J., Torres Alcantara, A., Denegri, D. \& Carreazo, Y. association between social media use (twitter, Instagram, Facebook) and depressive symptoms: are twitter users at higher risk? Int J Soc Psychiatry, 2019; 65(1), 14-19, DOI: https://doi. org/10.1177/0020764018814270.

34. Frison E, Eggermont S. Browsing, posting and liking on Instagram: the reciprocal relationships between different types of Instagram use and adolescents' depressed mood. Cyberpsychol Behav Soc Netw. 2017;20(10): 603-9. https://doi.org/10.1089/cyber.2017.0156.

35. Stapleton P, Luiz G, Chatwin H. Generation validation: the role of social comparison in use of Instagram among emerging adults. Cyberpsychol Behav Soc Netw. 2017;20(3):142-9. https://doi.org/10.1089/cyber.2016.0444.

36. Baker DA, Algorta GP. The relationship between online social networking and depression: a systematic review of quantitative studies. Cyberpsychol Behav Soc Netw. 2016;19(11):638-48. https://doi.org/10.1089/cyber.2016.02 06.

37. Lin LY, Sidani JE, Shensa A, Radovic A, Miller E, Colditz JB, et al. Association between social media use and depression among US young adults. Depress Anxiety. 2016;33(4):323-31. https://doi.org/10.1002/da.22466.

38. Krylova D. The impact of social media on depression in 18-34-year- olds in the United StatesDoctoral dissertation, Florida Gulf Coast University; 2017.

39. Festinger L. A theory of social comparison processes. Hum Relat. 1954;7: $117-40$.

40. Yang CC, Robinson A. Not necessarily detrimental: two social comparison orientations and their associations with social media use and college social adjustment. Comput Hum Behav. 2018;84:49-57. https://doi.org/10.1016/j. chb.2018.02.020

41. Yang CC, Lee Y. Interactants and activities on Facebook, Instagram, and twitter: associations between social media use and social adjustment to college. Appl Dev Sci. 2018:1-17.

42. Balshem, et al. GRADE guidelines: 3 . Rating the quality of evidence. J Clin Epidemiol. 2011;64(4):401-6. https://doi.org/10.1016/j.jclinepi.2010.07.015.

\section{Publisher's Note}

Springer Nature remains neutral with regard to jurisdictional claims in published maps and institutional affiliations.
Ready to submit your research? Choose BMC and benefit from:

- fast, convenient online submission

- thorough peer review by experienced researchers in your field

- rapid publication on acceptance

- support for research data, including large and complex data types

- gold Open Access which fosters wider collaboration and increased citations

- maximum visibility for your research: over $100 \mathrm{M}$ website views per year

At BMC, research is always in progress.

Learn more biomedcentral.com/submissions 